Dr VLADIMIR PETROVIĆ, viši naučni saradnik

Institut za savremenu istoriju

Beograd, Republika Srbija

vladimir.lj.petrovic@gmail.com

originalan naučni rad

UDK: $323.1 / .2(497.1)^{\prime \prime} 1991 "$

$342.28(497.1) " 1991 "$

primljeno: 20. februar 2018.

prihvaćeno: 16 . maj 2018.

https://doi.org/10.29362/ist20veka.2018.2.pet.203-222

\title{
RASPAD SFRJ: PARALIZA, AGONIJA, RAT ${ }^{*}$
}

APSTRAKT: Članak se bavi uticajem raspada saveznog nivoa vlasti $u$ SFRJ na prerastanje jugoslovenske krize u oružani sukob. Izdvajaju se glavni akteri i ključne etape ovog procesa tokom prve polovine 1991, obeležene podelama unutar Predsedništva SFRJ, marginalizacijom Savezne skupštine i njenog Izvršnog veća, kao i rastućom autonomijom republičkih rukovodstava $i$ vojnog vrha. Na osnovu memoara protagonista $i$ dostupnog arhivskog materijala prati se blokada u radu saveznih institucija koja je onemogućavala rešavanje problema političkim putem i prerastala u paralizu tokom koje su se umnožavali oružani incidenti. Uzajamno podeljeni, nosioci savezne vlasti su abdicirali pred republičkim rukovodstvima, ili su suprotstavljenim akcijama otvorili put poslednjoj etapi jugoslovenske agonije.

KLJUČNE REČI: Predsedništvo SFRJ, Savezno izvršno veće, Jugoslovenska narodna armija, raspad Jugoslavije, vojni udar, Pakrac, Plitvice, Borovo Selo, Split

Prerastanje jugoslovenske krize u raspad zemlje obeležilo je 1990. godinu. Tokom naredne godine raspad je zadobio ratni karakter, a SFRJ je do izmaka 1991. nestala sa političke mape sveta. Među mnogim aspektima ovog složenog procesa posebnu važnost imao je raspad saveznih institucija. Erodiran krahom svoje glavne političke kopče, Saveza komunista Jugoslavije na vanrednom kongresu početkom 1990, ovaj nivo vlasti je zapadao u sve dublju krizu. ${ }^{1}$ Tokom te godine održani su višestranački izbori u svim republikama, ali ne i u federaciji, čime je značajno delegitimisana Skupština SFRJ. Podrivena je i jugoslovenska vlada (SIV), naročito nakon upada u devizni sistem zemlje koji je januara 1991. izvršila Srbija. Slovenija je u istom periodu tražila načina da realizuje plebiscitarnu odluku o nezavisnosti, dok je uvozom oružja u Hrvatsku i pobunom krajiških Srba u toj republici narušen i bezbednosni sistem zemlje, pa

\footnotetext{
* Rad je deo projekta Srpsko društvo u jugoslovenskoj državi u 20. veku-između demokratije i diktature (177 016), koji finansira Ministarstvo prosvete, nauke i tehnološkog razvoja Republike Srbije.

${ }^{1} \mathrm{O}$ razvoju jugoslovenske krize i njenom prerastanju u raspad tokom 1990. više: Vladimir Petrović, „Raspad SFRJ: kriza, erozija, pat“, Istorija 20. veka, br. 1, (2015), 117-132.
} 
se tako u ovoj fazi u rasplet krize aktivno uključila Jugoslovenska narodna armija (JNA). Međurepubličke razmirice su se odražavale u potpuno nekompatibilnim planovima za budućnost države, a Predsedništvo SFRJ je postalo servis republičkih interesa i poprište njihovih svađa. Savezni nivo vlasti je tako stavljen pred teške izazove, a uzajamni uticaj njegovih glavnih faktora tokom prerastanja jugoslovenskog raspada $u$ rat je predmet ovog članka.

\section{Savezni vrh: civilno-vojni odnosi i jugoslovenska kriza}

Zamršena arhitektura saveznog nivoa vlasti po Ustavu SFRJ iz 1974. bila je dodatno komplikovana jazom između zakonskih rešenja i realnosti. Ovaj raskorak se pokazao posebno značajnim za tok jugoslovenske krize u odnosu vojne strukture prema civilnim vlastima. Nakon Titove smrti ulogu šefa države preuzelo je kolektivno Predsedništvo SFRJ, postavši time „najviši organ rukovođenja i komandovanja oružanim snagama SFRJ u ratu i miru. “2 Međutim, dubina te kontrole nad najvećom komponentom oružanih snaga, Jugoslovenskom narodnom armijom, bila je veoma upitna. JNA nije, kako se verovalo, bila četvrta vojska po snazi u Evropi, ali jeste predstavljala veliki sistem od preko četvrt miliona ljudi. I doktrinarno, preko koncepta opštenarodne odbrane, ali i faktički, posredstvom miliona rezervista, vojska je bila isprepletana sa jugoslovenskim društvom. Njeno rukovodstvo je smatralo da ima neformalan mandat da se bavi sudbinom zemlje, izlazeći iz ustavnih okvira ukoliko je to nužno. ${ }^{3}$ Štaviše, armijski vrh je od druge polovine osamdesetih godina nastupao sa pretpostavkom da se protiv Jugoslavije vodi specijalni rat. Admiral Branko Mamula, savezni sekretar za narodnu odbranu od 1982. do 1988, tvrdi da su zbog toga razrađivani ,planovi pripravnosti za slučaj da Armija bude primorana preuzeti

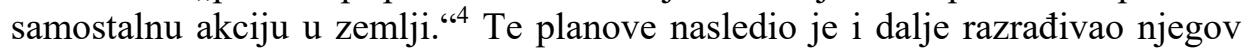

2 Član 313, stav 3, Ustav SFRJ (1974). O formiranju i funkcijama Predsedništva SFRJ detaljno: „Predsedništvo SFRJ: Nastanak, funkcije i sastav“", u: Od mira do rata. Dokumenta Predsedništva SFRJ, I, priredili Kosta Nikolić i Vladimir Petrović (Beograd: Institut za savremenu istorijuFond za humanitarno pravo, 2011), 9-20.

${ }^{3} \mathrm{O}$ specifičnom stanju u JNA u poslednjim godinama postojanja Jugoslavije videti: Miroslav Hadžić, Jugoslovenska narodna agonija (Beograd: Dangraf, 2004); Dragan Vukšić, JNA i raspad SFR Jugoslavije. Od čuvara do grobara svoje države (Stara Pazova: Tekomgraf, 2006); Davor Marjan, Slom Titove Armije. JNA i raspad Jugoslavije 1987-1992 (Zagreb: Golden Marketing, 2008); James Gow, Legitimacy and the Military: The Yugoslav Crisis (New York: St. Martin's Press, 1992). Takođe videti dokumentarni film Produkcijske kuće Mreža: JNA 19891992: Srpska verzija sloma, http://www.youtube.com/watch?v=dn_wShzIhN4, (pristupljeno 1. 5. 2018). U JNA je pred raspad služilo oko 25.000 oficira, 19.000 podoficira, 4.0000 zaposlenih civila i 190.000 regruta.

${ }^{4}$ Branko Mamula, Slučaj Jugoslavija (Beograd: Dan Graf, 2014), 164. Detalji tih planova nisu poznati, osim programa reorganizacije ustrojstva sprovedene 1987 (Davor Marijan, ,'Jedinstvo' - poslednji preustroj JNA“, Polemos, br. 1-2, (2003), 1-47; Bojan Dimitrijević, „Na nevidljivoj prekretnici: JNA u 1987. godini“", u: Slobodan Milošević - put ka vlasti. Osma sednica CK SKS, urednici Momčilo Pavlović, Dejan Jović i Vladimir Petrović, (Beograd: Institut za savremenu istoriju, 2008), 161-170). Genezu doktrine specijalnog rata u SFRJ analizirao je Cristian Costamagna, "Yugoslavia and the Special War in Late Socialism: New Research Perspectives", Serbian Studies Research, no. 1 (2017), 121-152. 
naslednik, general Veljko Kadijević. Političko rukovodstvo zemlje, kako svedoči tadašnji predsednik Predsedništva SFRJ Raif Dizdarević (1988-89), nije imalo uvid u razmere ovih planova, kao ni presudan uticaj na kadrovska rešenja u ovoj, takozvanoj „,sedmoj republici“ Jugoslavije. ${ }^{5}$

Još je manje mogućnosti za sprovođenje bilo kakve civilne kontrole vojske imao predsednik Saveznog izvršnog veća, iako je ovo telo bilo zaduženo da ,usklađuje i usmerava rad saveznih organa uprave“6. ${ }^{6}$ Kada je 16. marta 1989. na ovo mesto izabran Ante Marković, bio je u prilici da samostalno formira svoj ekonomski tim, ali je imao manje uticaja na ,resore sile“. Na insistiranje Srbije, savezni sekretar za unutrašnje poslove postao je general Petar Gračanin, dok je na mestu saveznog sekretara za narodnu odbranu Marković iz prethodne vlade Branka Mikulića jednostavno nasledio Veljka Kadijevića, koji je sa velikim podozrenjem pristupao premijeru i njegovom programu ekonomske reforme. U njemu je video eksponenta Zapada, dok je za Markovića Kadijević bio upravo oličenje onoga protiv čega se borio - okoštalog titoizma branjenog osloncem na Istok. Raspad Saveza komunista Jugoslavije (SKJ) u januaru 1990. ogolio je ovaj procep u saveznom vrhu, i mogao se iščitati čak i iz imena organizacije čiji su nastanak inspirisali u susret višestranačkim izborima - Marković je u leto 1990. osnovao Savez reformskih snaga Jugoslavije, dok je Kadijević na jesen podstakao transformaciju organizacije SKJ u JNA u Savez komunista - pokret za Jugoslaviju (SK-PJ). Međutim, uprkos učešću velikog broja aktivnih i penzionisanih starešina, nije delovalo da će SK-PJ izrasti u realnu političku snagu, baš kao što su se i Markovićevi reformisti organizovali prekasno da bi ostvarili značajniji rezultat na republičkim izborima. ${ }^{7}$

Kako su se Slovenija i Srbija, svaka iz svojih razloga, opirale ideji da se održe i izbori na federalnom nivou, akteri saveznog nivoa vlasti bili su svedeni na posmatrače transformacije republičkih političkih sistema i njihovo međusobno udaljavanje. Armija se nije mirila sa ovakvom ulogom. Nakon smrti Tita i raspada SKJ, JNA je sagledavana, a i doživljavala se kao poslednja opštejugoslovenska institucija, ustavno obavezana da štiti ,nezavisnost, suverenitet, teritorijalnu celokupnost i ovim ustavom utvrđeno društveno uređenje Socijalističke Federativne Republike Jugoslavije“" 8 Podozrevajući da se u Sloveniji radi na promeni kako sistema, tako i

${ }^{5}$ Raif Dizdarević, Od smrti Tita do smrti Jugoslavije. Svjedočenja (Sarajevo: Svjetlost, 2000), 401-402.

${ }^{6}$ Član 347, stav 1, Ustav SFRJ (1974).

${ }^{7}$ Osnovan u leto 1990. velikim mitingom na Kozari, Savez reformskih snaga Jugoslavije je propustio izbore u Sloveniji i Hrvatskoj. Uzeo je učešća na novembarskim izborima u Bosni i Hercegovini, ali je osvojio tek 13 od 240 mandata njene dvodomne Skupštine. Na izborima u Crnoj Gori decembra 1991. Savez reformskih snaga je dobio 13,6\% glasova, dok je na istovremenim predsedničkim izborima u Srbiji kandidat Ivan Đurić koga su reformisti podržavali dobio 5,5\% glasova. Vladimir Goati, Izbori u SRJ od 1990. do 1998 (Beograd: CESID, 2001), 210.

8 Član 240, Ustav SFRJ (1974). Iako je bilo tačno da su Srbi i Crnogorci predstavljali natpolovičnu većinu oficirskog kadra, ta se prednost gubila u najvišem ešalonu. Srbi, kojih je bilo $40 \% \mathrm{u}$ Jugoslaviji, 1981. sačinjavali su $60 \%$ oficirskog kadra, ali ih je u generalitetu bilo $44 \%$. Siniša Tatalović, „Civilno-vojni odnosi“, Politička misao, XXXIV, br. 2, (1997), 74. Na tzv. nacionalni ključ se posebno pazilo na najosetljivijim funkcijama, u skladu sa članom 242. Ustava koji je predviđao „načelo što srazmernije zastupljenosti republika i autonomnih pokrajina“. Načelnik 
granica zemlje, armijski vrh je sve dublje ulazio u konflikt sa slovenačkim rukovodstvom, a vojna bezbednost je tokom čitave druge polovine 1990. prikupljala materijal o ilegalnom naoružavanju Hrvatske. Teško i da je vojsci promaklo približavanje stavova između srpskog i slovenačkog rukovodstva o izlasku Slovenije iz Jugoslavije, kao i uloga Srbije u ,balvan-revoluciji“" u Hrvatskoj.

Dok je kriza prerastala u raspad, od vojske se puno i očekivalo, kako u krugovima njenih simpatizera, tako i među njenim protivnicima. „Svaki dan smo očekivali da vojska preuzme vlast", seća se Danica, supruga Dragana Atanasovskog, predsednika SK-PJ, partije koja se pripremala da u tom slučaju obezbedi civilnu administraciju vojnoj upravi. ${ }^{9}$ Izgledalo je da se stvari kreću baš u tom pravcu krajem januara 1991, kada Televizija Beograd emituje film o naoružavanju Hrvatske, snimljen na osnovu materijala koje je prikupila Uprava bezbednosti JNA, a koji je implicirao hrvatskog ministra odbrane Martina Špegelja i druge visoke zvaničnike. Pod tim utiskom, Dušan Bilandžić zapisuje u dnevnik: „Hrvatska već danima ne spava“. ${ }^{10}$ Vojska se, međutim, opredelila da političkim pritiskom na sednici Predsedništva SFRJ iznudi razoružanje od hrvatskog rukovodstva. ${ }^{11}$ Kako je umesto toga u Hrvatskoj povećan rezervni sastav policije, a Sabor je 22. februara prihvatio Rezoluciju o razdruživanju od SFRJ i potvrdio da republički zakoni imaju primat nad saveznim, vojni vrh sa srpskim rukovodstvom deli planove ,da se kombinovanim političkim i vojnim merama sruši vlast prvo u Hrvatskoj, a potom u Sloveniji. “12 Istovremeno je Srpsko nacionalno vijeće SAO Krajine usvojilo Rezoluciju o razdruživanju od Hrvatske. Uže srpsko-hrvatskih odnosa je sa obe strane zatezano do pucanja, pa su tako pucnji i odjeknuli u Pakracu 1. marta 1991. prilikom srpskog pokušaja preuzimanja policijske stanice, koji je osujetila intervencija MUP-a Hrvatske uz cenu od tri ranjena. ${ }^{13}$ Samo je sticaj okolnosti sprečio veće ljudske žrtve - rat je kucao na vrata.

U ovoj fazi se u pakračke događaje uključila Jugoslovenska narodna armija, poslavši 2. marta u Pakrac dve izviđačke čete i jednu mehanizovanu jedinicu, i stvarajući tako tampon-zonu između sukobljenih strana nakon što je hrvatska policija povratila kontrolu nad gradom. Vojni angažman u Pakracu neobično je podsećao na scenario raspleta jugoslovenske krize koji je Slobodan Milošević naznačio Bori-

Generalštaba je bio Srbin, Blagoje Adžić, ali su komandant mornarice Božidar Grubišić i vazduhoplovstva Anton Tus, bili Hrvati. Sam Veljko Kadijević, iz mešovitog braka Srbina i Hrvatice, deklarisao se kao Jugosloven, a njegov zamenik bio je Stanislav Brovet, Slovenac.

${ }^{9}$ Intervju sa Danicom Atanasovskom, Beograd, Srbija, 22. 1. 2017.

${ }^{10}$ Dušan Bilandžić, Povijest izbliza. Memoarski zapisi 1945-2005 (Zagreb: Prometej, 2006), 35.

${ }^{11} \mathrm{O}$ januarskoj sednici Predsedništva posvećenoj naoružavanju u zemlji više u: V. Petrović, $n$. $d$., $120-132$.

${ }^{12}$ Borisav Jović, Poslednji dani SFRJ (Beograd: Politika, 1995), 276-277, 281-282.

${ }^{13}$ Ovaj slavonski gradić je nastanjivalo nešto preko 8.000 stanovnika: 42,86\% Srba, 37\% Hrvata i $7,61 \%$ Jugoslovena. Skupština opštine Pakrac, kojom su dominirali srpski predstavnici, proglasila je 22. februara prisajedinjenje SAO Krajini, što je Ustavni sud Republike Hrvatske 28. februara poništio. Međutim, zapovednik pakračke policijske stanice Jovo Vezmar, koji je u međuvremenu ojačao brojno stanje aktivirajući pretežno Srbe iz rezervnog sastava, razoružao je 1. marta svoje hrvatske kolege. Rano ujutro 2. marta u gradu intervenišu specijalne jedinice hrvatskog MUP-a, dok se srpska rezervna milicija povlači ka Papuku uz razmenu vatre. 
savu Joviću, srpskom predstavniku u Predsedništvu SFRJ i predsedniku tog tela. „Čim proglase otcepljenje [Hrvatske] treba da im ga usvojimo, s tim da krajiške opštine držimo vojno, dok se narod na plebiscitu ne izjasni gde želi da živi." Stavio mu je čak u zadatak da za ovo rešenje pridobije vojno rukovodstvo: „Insistira da Veljka ubeđujem u tu varijantu. Ja sam oduvek bio za varijantu da ih preko noći odsečemo od Jugoslavije, pa neka idu u Evropu, ali vojska to ne prihvata“, zapisao je Jović. ${ }^{14}$ Stjepan Mesić, hrvatski član Predsedništva, smatrao je da vojska i srpsko rukovodstvo produbljavaju krizu da bi izborili ,izvanredna, ratna ovlašćenja za ondašnjeg predsjednika Predsjedništva g. Jovića, koji bi tako produžio predsjednički mandat koliko mu drago. [...] On niti je mogao, niti je smio u Pakrac poslati trupe bez odluke Predsjedništva, a učinio je to na zahtjev vojnog vrha“". ${ }^{15}$ Stoga je na hitno sazvanoj sednici Predsedništva SFRJ 2. marta uveče zahtevao objašnjenja o pokretu vojske. „Očigledno je prijetila, po nama, opasnost da dođe do mogućeg sukobljavanja. Onda smo mi predložili da se jedan broj jedinica pošalje koji će djelovati u smislu o kojem sam govorio. I predsednik se sa tim složio“, lakonski je objasnio Veljko Kadijević, zahtevajući još šira ovlašćenja od Predsedništva, od kojeg je očekivao da ,naloži armiji da upotrebi, pored ovih snaga koje su se tamo angažovale, dovoljno snaga koje će, vrlo brzo, uspostaviti mir, odnosno staviti situaciju potpuno pod kontrolu“. ${ }^{16}$ Međutim, umesto toga, otvorila se debata o političkoj pozadini vojnog angažmana u Pakracu. Jović je neuverljivo nastojao da opravda svoje postupke hitnošću situacije: „Ja sam smatrao da upozorenja, koje su mi dali organi, nedvosmisleno ukazuju da postoji opasnost međunacionalnih sukoba i da treba nešto da preduzmemo. [...] Onda sam ja, u dogovoru sa drugovima Gračaninom i Kadijevićem, zauzeo stav da vojska izađe tamo, ne da puca, ne da se bije, nego da izađe da bi se našla tamo - da se smiri situacija. “17

Jovića su podržali članovi Predsedništva iz Crne Gore (Nenad Bućin), sa Kosova (Riza Sapundžiju) i Vojvodine (Jugoslav Kostić), što je produbilo sumnje ostalih članova ovog tela da vojska koordinira svoju aktivnost sa srpskom stranom. Takvog mišljenja je bio Stjepan Mesić, dok je slovenački član Predsedništva Janez Drnovšek ,,protestirao prema današnjim aktivnostima predsednika Predsedništva SFRJ“ i postavljao pitanje odgovornosti za neovlašćeno pokretanje jedinica. ${ }^{18}$ Kadijević je reagovao oštro: „Samo nešto da kažem, oprosti. Imam ja, čak, mnogo veća prava - po Zakonu - u odnosu na pokretanje jedinica. Nijednu od tih nisam koristio, Janez“. ${ }^{19}$ On je od članova Predsedništva zahtevao da se poveća vojno prisustvo na

\footnotetext{
${ }^{14}$ B. Jović, $n . d ., 257$.

${ }^{15}$ Stjepan Mesić, Kako smo srušili Jugoslaviju. Politički memoari posljednjeg predsjednika Predsjedništva SFRJ (Zagreb: Globus 1992), 23.

16 „Stenografske beleške sa 102. sednice Predsedništva, 2. mart 1991“, u: K. Nikolić i V. Petrović, n. $d$., I, 326-327. Po Borisavu Joviću: „Naredio sam upotrebu vojske bez zasedanja Predsedništva, jer je bila nedelja. Članovi Predsedništva nisu bili u Beogradu. Malo su gunđali Janez i Vasil, ali je ipak odluka potvrđena.“ Međutim, nije bila nedelja već subota, a članovi Predsedništva nisu gunđali, već oštro protestovali. B. Jović, $n$. $d$., 281.

${ }^{17}$ K. Nikolić i V. Petrović, $n$. d., 348.

${ }^{18}$ Isto, 342.

${ }^{19}$ Isto, 353.
} 
terenu. Sem unutrašnjih opasnosti, nagoveštavao je i pretnju spoljnog faktora, bez sumnje iritiran pismom koje je povodom situacije u Pakracu stranim šefovima država uputio Franjo Tuđman, u kojem je video ,optuživanje JNA i pokušaj njenog razbijanja, i istovremeno, paralelno sa tim obraćanje strancima da dođu da intervenišu u Jugoslaviji.“ ${ }^{20}$ Kadijević je pretio: „Strani faktor može doći u Jugoslaviju samo ratom. [...] Nikakav NATO i nikakvi 'bogovi' neće doći ovdje - samo ratom“, upozoravao je ,prvi vojnik“ Jugoslavije svoju Vrhovnu komandu, čiji su članovi sve glasnije osporavali njegov autoritet. ,Drugovi, budite ljubazni - rata nam je dosta - da se javljate za reč‘, nastojao je Borisav Jović da povrati kontrolu nad tokom sednice. ${ }^{21}$ Uzalud; prema njegovim postupcima i vojnim predlozima podozrenje su pokazali Vasil Tupurkovski, makedonski član, kao i predstavnik Bosne i Hercegovine Bogić Bogićević: „Želim reći da sam, kao član Predsjedništva i formalno predsjednik Saveznog savjeta za zaštitu ustavnog poretka, o događajima u Pakracu obaviješten 15 sati posle sukoba“". 22 Sada je već polovina članova Predsedništva zamerala Joviću što je doneo inokosnu odluku, bez pokušaja da organizuje makar i telefonsku sednicu Predsedništva. Prepucavanje se nastavilo, a na jedvite jade sastavljeno zajedničko saopštenje Predsedništva jedva da je prikrivalo dubinu podela u ovom telu, koje su pakrački događaji i definitivno podelili na ,srpski blok“، (Borisav Jović, Jugoslav Kostić, Nenad Bućin, Riza Sapundžiju) i njegove oponente (Stjepan Mesić, Janez Drnovšek, Vasil Tupurkovski, Bogić Bogićević). Kadijeviću je ostalo samo da zaključi da sa postojećim ,stepenom angažovanja Armije ja ne odgovaram za mogućnost izbijanja međunacionalnog sukoba“. ${ }^{23}$

Ne samo što podeljeno Predsedništvo nije vojnom vrhu dalo očekivanu podršku, već se krajem iste nedelje zaljuljalo i pod prozorima Generalštaba u Beogradu, u kojem je veliki miting opozicije predvođen Vukom Draškovićem 9. marta prerastao u demonstracije koje su pretile da sruše režim Slobodana Miloševića. Policija nije uspela da obuzda demonstrante, Milošević je od Borisava Jovića zahtevao da naloži vojsci da obuzda demonstrante, a za to je bila potrebna odluka Predsedništva. Jović je telefonski nastojao da ostvari većinu. Nije uspeo, a verovatno ni pokušao da kontaktira Drnovšeka i Mesića. ${ }^{24}$ Podršku je dobio od ,srpskog bloka“, a nedostajući glas je dao Vasil Tupurkovski, koji je čitav dan odbijao da pruži suglasnost. Predomislio se tek u kasno popodne, nakon informacije da su sukobi u Beogradu već odneli dve žrtve, kada su poginuli mladi demonstrant Branivoje Milinović i milicioner Nedeljko Kosović: „Konačno, oko 6 uveče, kada me je Jović pozvao sedmi ili osmi put, rekao sam mu da ću glasati za jer je bilo žrtava i znao sam da će druge doći, situacija je izmicala kontroli, što je bilo očigledno, gledali smo na televiziji. “25 Armijski vrh je jedva dočekao odrešene ruke da nastupi protiv Vuka Draškovića, koji je tokom februara žestoko istupao protiv ideološke

\footnotetext{
${ }^{20}$ Isto, 347.

${ }^{21}$ Isto, $327,337$.

22 Isto, 340.

${ }^{23}$ Isto, 360.

${ }^{24}$ B. Jović, n. d., 283.

${ }^{25}$ Smrt Jugoslavije: Put u rat (BBC: 1995), 33.16. https://www.youtube.com/watch?v=Pr5GGW-4H7M.
} 
zaslepljenosti i ratobornosti jugoslovenskog generaliteta: „Neka u taj rat Brozovi generali i srpski komunisti vode svoje glave i svoju decu. Mi im decu Srbije ne damo. ${ }^{\text {26 }}$ Odgovor generala bile su tenkovske kolone koje su protutnjale Beogradom 9. marta uveče, olakšavajući policiji da neutrališe zadnje džepove demonstranata i da omogući da se, kako je general Blagoje Adžić preporučio srpskom ministru unutrašnjih poslova Radmilu Bogdanoviću ,jednostavno napravi jedna akcija juriša, u kojem treba da se bije do iznemoglosti.“‘27 Tako su, nakon Pakraca, oružane snage ponovo izvedene iz kasarni, ovoga puta da bi branile Miloševićev režim. Vojska je izmicala bilo kakvoj civilnoj kontroli, budući da se Predsedništvo podelilo po republičkim lojalnostima i izgubilo karakteristike jedinstvenog organa, dok je Savezno izvršno veće uspevalo da održi koheziju, ali ne i da nametne autoritet vojnom faktoru, koji se video kao odlučujući činilac u raspletu jugoslovenske krize.

\section{Od paralize do agonije: Vojni vrh i Predsedništvo SFRJ}

Nakon uspešne demonstracije sile u Beogradu, rukovodstvo JNA je u sadejstvu sa srpskim režimom pokazalo spremnost da sličan recept primeni na teritoriji čitave zemlje. Put ka tome tražen je u podizanju borbene gotovosti kroz uvođenje vanrednog stanja, pa time i neke vrste de facto vojnog udara. Međutim, do danas je ostalo nerazjašnjeno od koga je potekla ova inicijativa. Po generalu Kadijeviću, sve je pokrenuo Milošević, na prvom sastanku posle devetomartovskih demonstracija: „Nakon pozdrava Milošević je odmah bez nekog posebnog objašnjenja rekao da je situacija u zemlji takva da JNA treba da preuzme vlast, pohapsi sve koga treba i uvede red u zemlji“", što je Kadijević navodno odbio: „Ja sam odmah odgovorio, ne ulazeći u raspravu sa njim sledeće: da ja sam nikada tako sudbonosnu odluku neću doneti, jer ja imam Štab Vrhovne komande i da ću ja odmah čim stignem u Štab upoznati ga sa predlogom Miloševića. “28 Borisav Jović se međutim tih događaja seća potpuno drugačije: „Vojska već dugo najavljuje da će podneti Predsedništvu definitivne i odlučujuće predloge. Uprkos stalnim kontaktima sa Kadijevićem, moram da zabeležim da nije dovoljno jasno šta će vojska predložiti.“29 Šta je po Kadijeviću bio cilj? „Početna varijanta 'vojnog puča' bila je da se sačuva SFRJ kao cjelovita federalna država koja će najpre uraditi novi Ustav koji tu cjelovitost i federalno uređenje jasno i precizno definiše. Da se, zatim, sprovedu izbori i novo državno uređenje na novom Ustavu zasnovano konstituiše, kome bi, potom, JNA potpuno predala vlast i vratila se u svoju

${ }^{26}$ Vuk Drašković, „Šta hoće generali?““, Srpska reč, 18. 2. 1991, 11. U istom tekstu, Drašković je pozivao generale da odu u penziju: „Mladi, sposobni, školovani i demokratski nastrojeni oficiri danas su u zapećku." Hvatajući kontakt sa takvim kadrovima, on im je izlagao svoje viđenje razrešenja krize: ,'SSta čeka Vojska?' pitam, na tajnom sastanku trojicu mladih oficira. 'A šta vi čekate, gospodine Draškoviću?', uzvrati jedan od njih. 'Čekam vojni udar!', s neba ću pravo u rebra: 'Da se, istog dana, uhapse Slobodan Milošević, Franjo Tuđman i Alija Izetbegović'". Vuk Drašković, Meta (Beograd: Novosti, 2007), 52-53.

${ }^{27}$ Smrt Jugoslavije: Put u rat (BBC: 1995), 34.12. https://www.youtube.com/watch?v=Pr5GGW-4H7M.

${ }^{28}$ Veljko Kadijević, Protivudar. Moje viđenje raspada Jugoslavije (Beograd: Filip Višnjić, 2010), $137-138$.

${ }^{29}$ B. Jović, n. d., 286. 
normalnu ulogu. Ceo proces - od preuzimanja do predaje vlasti od strane JNA novoizabranim organima vlasti - trajao bi maksimalno godinu dana“. 30 Pod geslom zaštite savezne države, glavne mete bile su upravo njene institucije. Planirano je „smenjivanje Vlade i Predsedništva. Skupštinu neće dirati, ali neće ni dozvoliti sazivanje. Republičke vlasti i sve ostalo neće dirati ukoliko podržavaju udar. U protivnom skidaće i njih. " ${ }^{\text {31 }}$ Borisav Jović je bio sumnjičav prema takvom rešenju: „To je problem. Doživećemo krvoproliće, moraćemo da sprovodimo vojnu vlast bar godinu dana, bićemo izolovani od sveta“ $3{ }^{32}$ Međutim, uprkos strateškim i taktičkim razmimoilaženjima između srpskog i vojnog rukovodstva, Jović je 12. marta sazvao sednicu Predsedništva SFRJ u funkciji Vrhovne komande, što je trebalo da bude polazna tačka ove operacije. ${ }^{33}$

Kadijević je na toj trodnevnoj sednici zapravo nastojao da učini nešto neobično: da privoli političko rukovodstvo zemlje da proglasi vanredno stanje, dâ vojsci odrešene ruke i time se praktično samorazvlasti. Ovaj predlog je pravdao crtajući vrlo mračnu sliku stanja: ,Jugoslavija se našla u vrtlogu anarhije, raspada i na početku građanskog rata. Blokirani su razgovori o političkoj budućnosti zemlje. Na djelu je perfidan i do kraja razrađen koncept razbijanja Jugoslavije. Njegove uporišne tačke čini težnja da se politikom svršenog čina blokiraju osnovne funkcije federalne države, da se uporedo sa razgradnjom federacije razbiju oružane snage i onesposobe za ostvarenje svoje ustavne uloge, da se izazivanjem građanskog rata stvore uslovi za spoljnu intervenciju i definitivnu uspostavu marionetskih režima na tlu Jugoslavije. ${ }^{634}$ Zahtevao je odluku Predsedništva o zavođenju vanrednog stanja i podizanju borbene gotovosti JNA, uz mobilizaciju potrebnu za suprotstavljanje dezintegrativnim tendencijama. „Vi to, drugovi i gospodo, tolerišete (...) mi više nemamo prostora za strpljenje“،, bio je još oštriji načelnik Generalštaba Blagoje Adžić. ${ }^{35}$ Generali su streljali očima svoju Vrhovnu komandu, dok je vojna kamera budno snimala reakcije osmorice članova Predsedništva, sabijenih u hladno podzemlje vojnog objekta Karaš na Topčideru, pokrivenih šinjelima koji su im dati na ulazu. Međutim, uprkos ovom pritisku, efekat je izostao - članovi Predsedništva i dalje nisu ostvarili potrebnu većinu za armijski predlog. ${ }^{36}$ Dogovoreno je da se sednica nastavi prekosutra.

${ }^{30}$ V. Kadijević, $n . d ., 153$.

${ }^{31}$ B. Jović, $n$. d., 295.

${ }^{32}$ Isto, 247.

${ }^{33}$ Kako je ova sednica održana u vojnim prostorijama i nije stenografisana po uobičajenoj proceduri Predsedništva, još uvek nije dostupan njen kompletan transkript. Delimična rekonstrukcija je objavljena u: K. Nikolić, V. Petrović, $n$. d., 370-395. Osnovu su predstavljali fragmenti stenograma koje su u svojim memoarima preneli Janez Drnovšek, Stjepan Mesić i Borisav Jović, kao i fragmenti snimaka sednica koje je Služba za informisanje SSNO iskoristila za dokumentarnu emisiju „Ko izdaje zemlju“, prikazanu na TV Beograd 2. oktobra 1991. https:// www.youtube.com/watch?v=TxZjGazwZPs, a štampanu u Narodnoj armiji tri dana kasnije.

${ }^{34}$ K. Nikolić, V. Petrović, n. d., 371.

${ }^{35}$ Isto, 375-378.

${ }^{36}$ Stjepan Mesić: „Bilo je isključeno centralno grijanje u prostoriji gdje smo mi zasjedali i onda nam je vojska 'širokogrudo' ponudila vojne šinjele, baš vojne šinjele, računajući da nas na taj način uniformiraju, pa da neko 'pukne' i da glasa za ono što vojska traži. General Veljko Kadijević je 
Kadijević je iskoristio pauzu u zasedanju da 13. marta inkognito poseti Moskvu, da bi ministra odbrane SSSR-a maršala Dimitrija Jazova upoznao sa planovima JNA i obezbedio sovjetsku podršku: „Odgovori su, nažalost, bili potpuno negativni, i svodili su se na to da na nikakvu podršku SSSR-a ne možemo računati. Naprotiv. Mi u Jugoslaviji moramo se osloniti na sopstvene snage. [...] Po povratku iz Moskve, isto veče, upoznao sam sa rezultatima posete predsednika Jovića i rekao mu da će Štab Vrhovne komande sutra na nastavak sednice izići sa nešto malo modifikovanim našim početnim predlogom, ali da suštinski nećemo ništa menjati. “37 Jović međutim tvrdi nešto potpuno drugo: ,Veljko nam je doslovno rekao u prisustvu generala Adžića: 'Idemo na vojni udar'. Nezavisno od toga da li će ili neće usvojiti predloženu odluku. ${ }^{638}$ Kako bilo, stav Predsedništva se nije izmenio. Odnos snaga se čak izmenio na gore po vojsku, jer je Riza Sapundžiju 14. marta glasao sa Mesićem, Tupurkovskim i Bogićevićem protiv uvođenja vanrednog stanja. U tome im se pridružio i Janez Drnovšek, pa su tako predloge JNA na novoj sednici od 15. marta podržavali još samo Borisav Jović, Jugoslav Kostić i Nenad Bućin. ${ }^{39}$ Budući da se i ova sednica završila bez pristanka, Kadijević je otvoreno pretio: „Mi kao vojska ćemo iz toga izvući pouke“ i podvukao armijsko ,pravo i obavezu da odmah nakon ove odluke proceni situaciju i povuče konsekvence koje iz nje proizilaze“. 40

Jović je zaključio sednicu, pa iste večeri podneo ostavku na mesto predsednika Predsedništva, obrazloživši svoje razloge u televizijskom prenosu: „Želim da obavestim sve građane Jugoslavije i jugoslovensku javnost da je rad Predsedništva SFRJ do te mere paralisan da je ono u ovim, za zemlju dramatičnim okolnostima, praktično prekinulo da vrši svoje ustavne obaveze i odgovornosti. Suočen sa činjenicom da je u Predsedništvu SFRJ prevladao odnos snaga koji nastoji vezati ruke JNA kao poslednjoj jugoslovenskoj instituciji, nisam u stanju da budem saučesnik u odlukama koje doprinose raspadu zemlje. Odlučio sam stoga da podne-

bio uvjeren da će nas slomiti na toj sjednici Predsjedništva. On nije bio nimalo korektan prema nama. Pri dolasku u salu sreo sam Bogića Bogićevića. Na njega je, moram reći, bio najveći pritisak. Imao sam informacije da je on cijelu noć pre toga proveo u razgovorima s generalima koji su ga pritiskali svim mogućim pritiscima i argumentima da poklekne i da glasa za srpski prijedlog, računajući na to da je on Srbin. Međutim, on je glasao protiv uvođenja izvanrednog stanja i onda ga je Bora Jović nakon glasovanja pred svima vrlo glasno i arogantno pitao: - Bogiću, ti si Srbin, zašto ne glasaš kao i ostali? Bogić mu je odgovorio: - Slušaj Boro, zapamti, ja jesam Srbin, ali prije svega sam Bosanac i glasam za interese cijele Jugoslavije, a time i za interese Bosne i Hercegovine“ (Stjepan Mesić, „Ja sam dogovorio sastanak u Karađorđevu“, https://www. slobodnaevropa.org/a/1045335.html). „I Bogić nije glasao [...] Jović je počeo da viče: 'Glasaj za, glasaj protiv, šta je bitno!' Drao se. Bukvalno se drao. I tu je zemlja visila o svojoj sudbini, i Bogić nije glasao [...] i tu se sastanak istog trenutka raspao (Vasil Tupurkovski, „Raspad je bio neminovan, ali ne i rat", https://www.slobodnaevropa.org/a/1045340.html). Sam Bogićević je ovako tumačio svoj postupak: „Razmišljao sam u kategorijama - protiv koga? Niko Jugoslaviju nije napao ni izvana niti iznutra. Protiv nas samih da povedemo rat, zašto?“ („Bogić Bogićević: čovjek koji je rekao ne“, https://www.slobodnaevropa.org/a/1045338.html).

${ }^{37}$ V. Kadijević, $n$. d., 147.

${ }^{38}$ B. Jović, n. d., 295.

${ }^{39}$ K. Nikolić, V. Petrović, $n$. d., 380-390.

${ }^{40}$ Isto, 390. 
sem ostavku na dužnost“".41 Sutradan je i Milošević u javnom obraćanju preko Televizije Beograd objavio da je Jugoslavija ušla u ,završnu fazu svoje agonije“. Podvukao je da je Predsedništvo u disfunkciji i da po njegovoj oceni još jedino JNA brani interese čitave zemlje, ali nije krio ni svoj alternativan plan: „Od Vlade Republike Srbije zatražio sam da izvrši sve pripreme za formiranje dodatnih snaga u obimu i veličini koje će garantovati zaštitu interesa Republike Srbije i srpskog naroda“. ${ }^{42}$ Iza zatvorenih vrata, na sastanku sa opštinskim rukovodiocima svoje stranke bio je još eksplicitniji: ,Granice, kao što znate, uvek diktiraju jaki, nikada ne diktiraju slabi. A ako treba da se tučemo, bogami ćemo da se tučemo. Jer, ako ne umemo dobro da radimo i privređujemo, bar ćemo znati dobro da se tučemo. ${ }^{\text {‘43 }}$ Takođe je od Skupštine Srbije zatražio da razreši dužnosti Rizu Sapundžiju. Kako su Nenad Bućin i Jugoslav Kostić takođe podneli ostavke, bilo je teško oteti se utisku da je srpska strana uradila sve da otvori vojsci prostor za akciju.

Preostali članovi Predsedništva, predvođeni Mesićem i Tupurkovskim, improvizovali su sednicu ovog tela 16. marta, na koju su pozvali i druge savezne funkcionere. Na sednicu je došao Ante Marković, ali ne i Kadijević i Gračanin, iako ministri u njegovoj vladi. Odlučeno je da se na konferenciji za štampu javno saopšti da Predsedništvo funkcioniše i da se time suzbiju ili ogole namere vojnog vrha. ${ }^{44}$ Vojska je na to reagovala trodnevnim ćutanjem, iza kojeg je usledilo konfuzno saopštenje od 19. marta: „Budući da Predsedništvo SFRJ nije prihvatilo predlog neophodnih mera, JNA ne može snositi odgovornost za dalje eventualno nelegalno naoružavanje građana i njihovo vojno organizovanje na bilo kom delu jugoslovenske teritorije. JNA se, kao ni do sada, neće mešati u političke dogovore o budućnosti zemlje“. ${ }^{45}$ Prethodno je na sastanku sa srpskim rukovodstvom admiral Stane Brovet objasnio ovaj antiklimaks procenom vojnog vrha da za ambicioznije planove ne postoji ni spoljna ni unutrašnja podrška. „Eto, to je sve“, zapisao je Borisav Jović. „Ispali su krajnje čudni. Mi ih nismo terali da vrše vojni udar. Nisu bili iskreni ni prema meni ni prema Slobodanu, a želeli su da im mi budemo političko pokriće." "46 Milošević je pragmatično zatražio garanciju da će vojska ponovo priteći u pomoć u slučaju demonstracija u Beogradu, a zatim je srpska skupština naložila Joviću i Kostiću da povuku ostavke i vrate se u Predsedništvo, a umesto Sapundžije izabrala je Sejdu Bajramovića, dok je Skupština Crne Gore umesto Nenada Bućina imenovala Branka Kostića. „Državne udare vrše pukovnici, a ne generali“, rezignirano je zaključila Danica Atanasovska. ${ }^{47}$

Tako pokušaj uvođenja vanrednog stanja nije postigao ništa osim definitivne paralize Predsedništva, koja je i ozvaničena kada se to telo sastalo u proširenom sastavu 21. marta 1991. godine. Ne samo što mandati članova Predsedništva

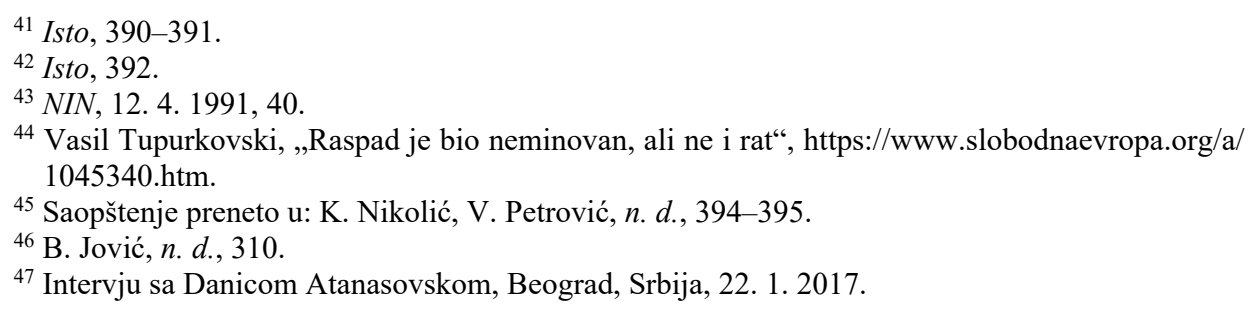


koji su podneli pa povukli ostavke nisu potvrđeni, već je sednica protekla u duhu uzajamnih optužbi saveznih funkcionera. Ante Marković je zahtevao „da se stavi na dnevni red javna optužba predsjednika Predsjedništva Jugoslavije u ostavci da je Savezno izvršno vijeće agent inozemnih i drugih službi pa i država“", i pretio da će ,SIV pokrenuti sudski spor, što će isto biti jedan jugoslavenski nonsens, ali ipak, neka bude“". ${ }^{48}$ Jović je predlagao da će sve te optužbe ponoviti pred Skupštinom SFRJ. ${ }^{49}$ Prisutnim republičkim liderima nije teško palo prepucavanje između saveznih kolega. Tako su Kučan i Milošević šaljivo insistirali da u zapisnik zasedanja uđe „da će predsednik SIV-a da tuži predsednika Predsedništva“" ${ }^{50}$ Erodiranje i delegitimisanje saveznih institucija je povećavalo značaj republičkih, i zapravo je bilo u duhu odluka sa ovog sastanka, na kojem je dogovoreno da se razgovori o političkoj budućnosti Jugoslavije prenesu sa Predsedništva na direktne kontakte predstavnika republika. ${ }^{51}$ Time je, međutim, agonija produžena. Već nakon prvog sastanka, 28. marta u Splitu, usledio je novi oružani sukob na Plitvicama, sa po jednom žrtvom na obe strane - poginuli su krajiški milicioner Nikola Vukadinović i hrvatski specijalac Josip Jović. Neometani ovim događajima, predsednici republika nastavljaju sa besperspektivnim sastancima i konfliktnim konferencijama za štampu tokom aprila. Od Splita i Beograda preko Brda kod Kranja do Ohrida i Cetinja, sastanci su bili tako jalovi da su ih savremenici nazvali ,putujući cirkus“, ,paket aranžman“ ili „mlaćenje prazne slame“. 52

\section{Od agonije do rata: Vojni vrh i Savezno izvršno veće}

Tako su savezni funkcioneri od aktera postali tek skrajnuti posmatrači političkog procesa. Pozivani su na republičke samite kao dežurni krivci za razmere raspada zemlje, budući da je kritika saveznih organa vlasti bila jedna od retkih tačaka oko koje su suprotstavljeni republički lideri mogli da se saglase. Svako je

${ }^{48}$ K. Nikolić, V. Petrović, $n$. d., 403.

${ }^{49}$ Ovo je zapravo bila karikatura člana 320 stava 4 Ustava SFRJ: „Ako Predsedništvo SFRJ zadrži od izvršenja propis SIV-a, izneće sporno pitanje pred nadležno veće Skupštine SFRJ radi donošenja odluke.“

${ }^{50}$ K. Nikolić, V. Petrović, n. d., 460.

${ }^{51}$ „Stenografske beleške sa 108. sednice Predsedništva“, u: K. Nikolić, V. Petrović, n. d., 396-463.

52 Jedan od razloga neproduktivnosti republičkih samit-sastanaka bio je i taj što su se njihovi ključni akteri, Slobodan Milošević i Franjo Tuđman, tokom istog perioda sastajali nasamo, prvo u Karađorđevu 25. marta, a zatim u Tikvešu 15. aprila. U međuvremenu su opunomoćili ekspertske komisije da rade na normalizaciji odnosa. Iako snimci sa ovih razgovora nisu nikada ugledali svetlost dana, među savremenicima preovladava utisak da su na njima pokrenute ključne teme koje su uticale na dalji tok krize. Izgleda da su dve osnovne dodirne tačke ovih naoko potpuno suprotstavljenih političkih figura bile ne samo podela interesnih sfera u Bosni i Hercegovini, već i rušenje vlade Ante Markovića (Svjedoci raspada: Stjepan Mesić, Omer Karabeg (Prag: Radio Slobodna Evropa, 2008), https://www.slobodnaevropa.org/a/1045335.html. i Međunarodni krivični tribunal za bivšu Jugoslaviju (MKSJ), Predmet Milošević, Svedočenje Hrvoja Šarinića; http://www.icty. org). Tezu o presudnom značaju dogovora između Tuđmana i Miloševića na dalji tok jugoslovenske krize najdalje dovode autori dokumentarnog filma Dogovoreni rat Slađana Zarić, Filip Čolović, Informativni program RTS, 2011 (https://www. youtube.com/watch?v=K38-YhyopCU). Tu tezu najdoslednije ali i najneuverljivije opovrgava Ivo Lučić: „Karađorđevo: politički mit ili dogovor?", Časopis za suvremenu povijest, br. 1, (2003), 7-36. 
imao svoju metu. Milanu Kučanu je najveći trn u oku predstavljalo rukovodstvo JNA, dok su protiv Saveznog izvršnog veća istupali Slobodan Milošević i Momir Bulatović. Antu Markovića su branili Kiro Gligorov i Alija Izetbegović, dok je Franjo Tuđman zahtevao preispitivanje rada svih saveznih institucija. ${ }^{53}$ Uzalud je pred ohridsku sednicu 18. aprila Bogić Bogićević podsećao da baš te njihove republičke kolege ,već dugo imaju odlučujuću riječ.“ Njegov kolega iz Predsedništva, Jugoslav Kostić, došao je na Ohrid sa očekivanjem ,da se konačno dogovorimo da razrešimo ovu našu agoniju“. ${ }^{44}$ Nije samo on razmišljao o presecanju agonije. Pravljene su najrazličitije prevratničke kombinacije, čiju je težinu i ozbiljnost teško oceniti. Tako admiral Branko Mamula tvrdi da mu je američki ambasador preko posrednika ,sugerirao da JNA treba uhapsiti šestoricu u Ohridu i preuzeti vlast u zemlji“" ${ }^{55}$ Kako bilo, sam Mamula je svakako bio mišljenja da političko uporište vojnog udara treba tražiti na saveznom nivou, i to u vladi, a ne u Predsedništvu čiji su članovi bili eksponenti republičkih interesa.

Međutim, premda su i vojska i vlada deklarativno nastupale sa jugoslovenskih pozicija, Ante Marković i Veljko Kadijević su nastojali, ali nikako nisu uspevali da prevaziđu uzajamno nepoverenje i približe stavove, a kamoli da osmisle modalitete eventualne saradnje: „U mom kabinetu, kad smo bili sami, takve se stvari ne pričaju pred trećima, Kadijević mi je rekao da su oni razradili u Generalštabu cijeli plan o tome kako će pohapsiti Tuđmana i rukovodstvo Slovenije, i da oni imaju sve potrebne pretpostavke, predloge, i sve spremno da mogu to napraviti. Kažem: gdje ti je tu Milošević i njegovo rukovodstvo? Onda je on skočio, sav bijesan: On je jedini koji se bori za Jugoslaviju. Da njega nema, mi to ne bismo mogli ni predlagati." Po Markoviću, Kadijević je predlagao sledeće: „Pošto je Predsjedništvo nesposobno donijeti odluku, mi donosimo tu odluku i predlažemo da ti to podržiš, i da se nakon toga, kad mi to provedemo, zapravo, izvrši i smjena Predsjedništva, a kako si ti najstariji funkcioner u Federaciji, jer si legalno izabrani predsjednik Vlade, da preuzmeš i funkciju predsjednika države (...) što sam, naravno, apsolutno i s gnušanjem odbio jer nije on mogao pohapsiti rukovodstvo, a da ne dođe do krvi. To je bilo jasno“. ${ }^{66}$ Kadijević se ovog razgovora drugačije sećao, tvrdeći da je vojni udar zapravo bio Markovićeva ideja, sa kojom se on nije saglasio: „Nerealno, neostvarljivo. On nije video čak ni prvi korak, ako bi se prihvatio taj njegov predlog. On je video samo kako bi on postao lider Jugoslavije, to je video. A šta će iz toga ispasti, kako će na to reagovati srpsko stanovništvo, koje je tada imalo specifičan odnos podrške prema Miloševiću, i kako će reagovati hrvatsko stanovništvo, koje je imalo preko 90\% podrške Tuđmanu?“"57 Stoga je Marković tokom martovskog pokušaja uvođenja vanrednog stanja potpuno skrajnut od vojske, koja se čak

53 „Zapisnik razgovora predsjednika republika i predsjednika Predsjedništava republika, Split, 28. ožujka 1991", National Security and the Future, XIV, no. 3-4, (2013), 104-161.

54 Kamera pamti, Svetolik Milić (Beograd: RTS 1995), 3.43.00. https://www.youtube.com/ watch? $\mathrm{v}=9$ EebziKCLUs.

${ }^{55}$ B. Mamula, $n . d ., 193$.

${ }^{56}$ Ante Marković, „Moja istina o smrti Jugoslavije“, Danas, Beograd, 13-28. 11. 2003.

${ }^{57}$ Intervju Veljka Kadijevića RTS, Moskva, 2007. https://www.youtube.com/watch?v=EQnI63bhAq4. 
oglušila na njegov poziv: ,SIV je već danas zakazao sednicu sa kolegijumom SSNO što je od strane vojske odbijeno. Niko neće ići na tu sednicu“, likovao je Borisav Jović. ${ }^{58}$ Marković je uzvratio, svrstavši se protiv vojnog vrha svojim dolaskom na improvizovanu sednicu krnjeg Predsedništva 16. marta: „Mi smo tada pokazali da Predsjedništvo funkcionira“. ${ }^{59}$ Međutim, sa njim se nije pojavio Kadijević, koji je nakon toga potpuno prestao da posećuje sednice vlade.

Neki oblik komunikacije među ovim akterima saveznog nivoa vlasti obnovljen je tek nakon mesec dana, pod uticajem međurepubličkih samita koji su odgovornost za nastalo stanje prebacivali na federaciju. Marković je i taj udarac uzvratio u obraćanju Skupštini SFRJ od 19. aprila, u kojem je podvukao odgovornost republičkih rukovodstava za stanje u zemlji: „Derogiranje saveznih propisa postalo je preovlađujuće ponašanje, a davanje primata republičkim propisima ozbiljno je potkopalo same temelje pravnog sistema. Proboj u platni sistem i uzimanje tuđih novaca, sve je to vodilo ne samo u pravnu anarhiju, nego i u ekonomski kaos.“ U istom govoru pokazao je iznenađujući stepen razumevanja za probleme JNA: „U ovoj situaciji posebno je delikatan položaj Jugoslavenske narodne armije. Ona je bila i jeste izložena raznim pritiscima, od onih da potpuno zanemari svoju ustavnu ulogu i zadatke i bude pasivan posmatrač procesa i pristane na vlastito raspadanje, do zahtjeva da svojom neposrednom, oružanom intervencijom, dakle silom, omogući isključivo jednu opciju u razrješenju jugoslavenske krize. Međutim, činjenica da je, bez obzira na neke krizne momente u kojima je moglo doći do takvog razvoja događaja, u cjelini gledano JNA je, uvažavajući realitet demokratskih procesa u zemlji, ostala u okvirima svoje ustavne pozicije. ${ }^{\text {"60 }}$ Sticao se utisak da Marković ostavlja otvorena vrata za neku vrstu saradnje sa vojskom.

Međutim, ako je Marković i slao signale vojsci, oni nisu bili ni do kraja jasni, niti su dobro primljeni pokušaji da se ovaj jaz premosti, iako nije manjkalo posrednika. Sem Mamule, na tome je po Kadijeviću radio čak i Stjepan Mesić, u nameri da obezbedi svoju predstojeću inauguraciju na mesto predsednika Predsedništva: „Preko Ante Markovića, pokušao je da i mene angažuje, naravno i vojsku, da srušimo Tuđmana koji je po njemu apsolutista a na čelo Hrvatske dovedemo Mesića koji je demokrata i liberal. Marković je jednom drugom prilikom pokušao da uveri mene kako bi trebalo srušiti Miloševića i Tuđmana, pa bi svi problem u Jugoslaviji bili rešeni. Sa tim predlogom je došao kod mene u maju 1991. vojnim helikopterom u Karađorđevo gde sam se ja nalazio na bolovanju. To je bila tipična Markovićeva improvizacija u kojoj je on od svega što bi takav pokušaj izazvao u Jugoslaviji, video samo eventualno prvi čin u kome bi on, pomoću vojske, došao na čelo Jugoslavije. Druge katastrofalne posledice on nije bio u stanju da vidi."61 Zapravo, nije se radilo samo o uzajamnom podozrenju, već i o različitim koncepcijama Markovića, koji je želeo da očuva

\footnotetext{
${ }^{58}$ B. Jović, n. d., 308.

${ }^{59}$ A. Marković, „Moja istina o smrti Jugoslavije“, Danas, Beograd, 13-28. 11. 2003.

${ }^{60}$ Borba, 20-21. 4. 1991, 2.

${ }^{61}$ V. Kadijević, n. d., 244. O razmimoilaženjima u vrhu SIV-a piše njegov portparol Predrag Tašić, Kako sam branio Antu Markovića (Skopje: Mugri 21, 1993).
} 
zemlju, ali da promeni sistem sa njegovom ideološkom podlogom, i Kadijevića koji se smatrao zatočnikom tog sistema, čak i po cenu opstanka zemlje.

Definitivno digavši ruke od Kadijevića početkom maja, Marković je počeo da razmatra mogućnost njegove smene, za koju se posebno zalagao savezni sekretar za spoljne poslove Budimir Lončar. ${ }^{62}$ Isprečila se, međutim, ustavna prepreka - predsednik SIV-a je mogao samo da predlaže razrešenja svojih saveznih sekretara. ${ }^{63}$ Odluku je donosila Skupština SFRJ, čiji je rad uglavnom bio u blokadi. „O tome sam razgovarao s ministrom unutarnjih poslova Hrvatske, Josipom Boljkovcem“, sećao se Marković: „Boljkovcu sam rekao: kad bi se slovenski i hrvatski predstavnici pojavili samo na jedan dan, taj dan bih mogao zatražiti Kadijevićevu smjenu i izglasavanje novog čovjeka za ministra Narodne obrane“. Njegov kandidat je bio Anton Tus, komandant ratnog vazduhoplovstva. „O tome sam s Tusom već razgovarao. Pošto su mene u Beogradu u to vrijeme pratili, sastajali smo se na Tuškancu i razgovarali šećući se. Tus je, na kraju, pristao, složio se da zamijeni Kadijevića. Preostalo mi je Tuđmanu objasniti kako je to prilika da se riješimo Kadijevića i neutraliziramo promiloševićevske snage u Armiji. S Tusom na čelu vojske, Mesićem na čelu Predsjedništva i sa mnom na čelu Vlade, Milošević više ne bi imao toliko manevarskog prostora, u svakom slučaju izgubio bi legitimitet. Stvari bi se možda odvijale sasvim drugačije “" ${ }^{64}$

Manevrišući tako između Kadijevića, Tuđmana i Miloševića, Marković je, ispostavilo se, ozbiljno potcenio kako njihovu spretnost, tako i spremnost da koriste ekstremna sredstva u odbrani svojih pozicija. Lanac krvavih i do danas nedovoljno rasvetljenih događaja prekinuo je njegovu kadrovsku vrtešku na saveznom nivou. Tako je niz incidenata u istočnoj Slavoniji kulminirao 2. maja, kada je u okršaju u Borovom Selu pored Vukovara poginulo 12 hrvatskih policajaca, dok su 22 ranjena, uz jednog poginulog i četiri ranjenika na srpskoj strani. ${ }^{65}$ Istog dana, na drugom kraju Hrvatske, u patroli u zaleđu Zadra gine hrvatski specijalac Franko Lisica, a u znak odmazde u gradu se uništava srpska imovina. U isto vreme, JNA blokira selo Kijevo kod Knina, a antiarmijski protesti se šire Hrvatskom, pa tako 6. maja u Splitu pred komandom Vojnopomorske oblasti pada prva žrtva na strani JNA, vojnik Saško Gešovski. Iako nije bilo jasno od čijeg je metka poginuo regrut, niti ko je i zašto naredio upad u Borovo Selo, a ko ga je branio, bilo je jasno da se dramatičnim eskaliranjem sa nekoliko strana radilo na podrivanju bilo kakvog dogovornog rešenja.

Jugoslovenska kriza je tako dosegla razmere oružanog sukoba. „Mi smo svjesni toga da smo zakoračili u jednu situaciju koja je početak općeg rata u našoj zemlji, koji bi se mogao katastrofalno završiti“, upozoravao je Marković članove Predsedništva na proširenoj sednici ovog tela, sazvanoj tim povodom 6. maja. Pre-

${ }^{62}$ Drago Hedl, „Budimir Lončar: Kadijević je za četvrtu generalsku zvijezdicu Miloševiću poklonio JNA“, Jutarnji, 6. 5. 2015.

${ }^{63}$ Član 349 Ustava SFRJ.

${ }^{64}$ A. Marković, „Moja istina o smrti Jugoslavije“, Danas, Beograd, 13-28. 11. 2003. Njegove navode potvrđuje i Josip Boljkovac, Istina mora izaći van. Sjećanja i zapisi prvog ministra unutarnjih poslova neovisne Hrvatske (Zagreb: Golden marketing, 2009), 236-246.

65 Vukovarska tragedija 1991, priredila Sonja Biserko (Beograd: Helsinški odbor za ljudska prava, 2007), 281-287. 
dložio je niz mera za predupređivanje širenja nasilja, ali su ostali savezni i republički učesnici bili okupirani prebacivanjem odgovornosti. ${ }^{66}$ Generali su za situaciju krivili političare: „Zato što predlozi Saveznog sekretarijata za narodnu odbranu nisu uvažavani, počeo je, naveliko, građanski rat u zemlji“‘. Zahtevali su da se obezbede uslovi za smirivanje situacije u zemlji, ali su se ogradili od daljeg toka ovih rasprava, smatrajući ih ,političkim razgovorima u kojima ne vide razloga da učestvuju“. 67 Istovremeno su najavili podizanje borbene gotovosti, pa i upotrebu vatre spram svakoga ko bude napadao vojsku. ${ }^{68}$ Vasil Tupurkovski je upozoravao da se ovakav „odnos mora hitno dovesti u ustavno stanje“، i ukazivao na opasnosti usled ,nepostojanje elementarne komunikacije u veoma kriznoj i delikatnoj situaciji“، ${ }^{69}$ Kako je rezimirao Borisav Jović, ,jedni misle da smo u građanskom ratu koji će se sve više rasplamsavati, a drugi da građanskog rata nema $i$ da je sve to umetno inscenirano“. ${ }^{70}$ Tako Predsedništvo nije uspelo čak ni da zajednički oceni situaciju, a kamoli da ponudi put ka njenom prevazilaženju. Anarhija u saveznim institucijama SFRJ je već bila takva da rat nije imao ko ni da objavi, a kamoli spreči.

U prepucavanju su najdalje išli srpski i hrvatski predstavnici. Hrvatski premijer Josip Manolić je optuživao Srbiju za ubacivanje naoružanih grupa na područje te republike, što je Slobodan Milošević kategorički poricao. ${ }^{71}$ Savezno izvršno veće je nastojalo da se postavi između suprotstavljenih strana, iznevši program koji je predviđao da se obezbedi pravna sigurnost građana, da se demobilišu rezervni policijski sastavi, da se omogući JNA da vrši svoju funkciju, da se spreče pokušaji promene unutrašnjih ili spoljnih granica zemlje, da se zaustavi propagandni rat te da se preduzmu mere protiv stranaka i pojedinaca koji raspiruju međunacionalnu mržnju i sukobe. ${ }^{72}$ Međutim, sukob je već tako daleko odmakao da je sve što je za hrvatsku stranu bilo previše, za srpsku bilo nedovoljno, i obrnuto. ${ }^{73}$ Situacija u Hrvatskoj je težila daljoj eskalaciji - na teritoriji 11 krajiških opština 12. maja je sproveden referendum o prisajedinjenju Srbiji i ostanku u Jugoslaviji, za šta se od 179.840 izašlih birača $\left(79,48 \%\right.$ od upisanih) opredelilo $179.490(99,8 \%) .{ }^{74}$ Ovim se nastojao preduprediti referendum o suverenosti na čitavoj teritoriji Hrvatske, raspisan za 19. maj. ${ }^{75}$ Sa obe strane se dolivalo ulje na vatru.

\footnotetext{
${ }^{66}$ MKSJ, Predmet Milošević, dokaz P330.2: Sednica Predsedništva SFRJ, 6. maj 1991, 22.

${ }^{67}$ Isto, Sednica Predsedništva SFRJ, 6. maj 1991, 17.

${ }^{68}$ MKSJ, Predmet Milošević, dokaz P330.2, Stavovi Štaba Vrhovne komande, 47.

${ }^{69}$ Isto, 16.

${ }^{70}$ Isto, 7.

${ }^{71}$ Isto, 20.

${ }^{72}$ MKSJ, Predmet Milošević, dokaz P330.2. Saopštenje sa sednice Saveznog izvršnog veća.

${ }^{73}$ Bez obzira na to što je saopštenje SIV-a eksplicitno pozvalo hrvatske organe ,da odmah preduzmu potrebne mere za zaštitu svih sloboda i prava građana na teritoriji republike Hrvatske, a posebno građana srpske nacionalnosti“, srpska vlada je pozivala Markovića na odgovornost zbog ,nevršenja Ustavom utvrđenih poslova i nepreduzimanja mera za zaštitu ljudskih prava i sloboda građana u republici Hrvatskoj“. Politika, 9. 5. 1991, 6-7.

${ }^{74}$ Peter Radan, „Republika Srpska Krajina and the Right of People to Self-Determination“, Istorija 20. veka, br. 1, (2018), 21.

${ }^{75}$ Ove referendume je smestio u kontekst i doveo u pitanje njihov liberalni karakter Dejan Jović, Rat i mit. Politika identiteta u suvremenoj Hrvatskoj (Zagreb: Fraktura 2017), 87-88.
} 
Skupština SFRJ je verno odražavala ovaj haos. Dok je njeno Savezno veće sve otvorenije zastupalo Miloševićevu liniju i zahtevalo raspravu o odgovornosti Saveznog izvršnog veća, hrvatska i slovenačka delegacija u Veću republika i pokrajina su 10. maja uzele učešća u radu samo da bi opstruirale izbor novih članova Predsedništva - Sejde Bajramovića sa Kosova i Branka Kostića iz Crne Gore, insistirajući na traženju mišljenja od Ustavnog suda Jugoslavije o legalnosti njihovog izbora. Predsednik Skupštine Slobodan Gligorijević kratko je prokomentarisao: „Nije dobro što se tako desilo, ali to je posledica velikih tenzija što je uslovilo da Skupština dosad nikada nije imala jedan ovakav nesretan završetak“. ${ }^{76}$ Zaključio je da će u Predsedništvu SFRJ Kosovo do daljeg predstavljati predsednik Skupštine Kosova Vukašin Jokanović, dok će Crnu Goru zastupati predsednik republičkog Predsedništva Momir Bulatović. Doveo je, međutim, u pitanje kompetentnost saveznog Predsedništva da u takvom sastavu donosi punopravne odluke. Tako je legitimitet Predsedništva doveden u pitanje u veoma osetljivom periodu, budući da je 15. maja predstojala uobičajena rotacija na funkciji predsednika Predsedništva SFRJ.

U Jugoslaviji, međutim, ništa više nije bilo uobičajeno. Sam Jović je u razgovoru sa Miloševićem zaključio ,da se rasplet jugoslovenske političke krize mora izvršiti dok sam ja na čelu Predsedništva SFRJ. Posle toga bili bismo potpuno nemoćni. Zato moramo vući poteze koji idu ka tome“. ${ }^{77} \mathrm{Ne}$ samo što je predsednik sazivao sednice Predsedništva i rukovodio njihovim tokom, već je po Ustavu u ime Predsedništva ostvarivao i komandovanje oružanim snagama SFRJ. ${ }^{78}$ Otuda ništa nije ukazivalo na mogućnost mirne primopredaje, koja bi na ovo mesto dovela Stjepana Mesića, iako je Slobodan Milošević uveravao američkog ambasadora u suprotno: ,Joviću neće biti produžen mandat. Doći će do uobičajene rotacije 15. maja. Srbija nikada neće pokušati da promeni način rotiranja jer poštuje savezni ustav. Gospodine Zimerman, možete obavestiti vašu vladu da apsolutno nema razloga da brine“. Međutim, Mesić je na sednici Predsedništva, pored sopstvenog, dobio glas iz Slovenije (Drnovšek), BiH (Bogićević) i Makedonije (Tupurkovski), ali su ga blokirali predstavnici Srbije (Jović), Crne Gore (Bulatović), Kosova (Jokanović) i Vojvodine (Kostić), što je Milošević ovako objasnio Zimermanu: ,Rekao sam Vam da Jović neće ostati na funkciji - i nije. Sve je bilo normalno. To što je se glasalo nije značilo da je Mesić morao da pobedi. Svaka zemlja radi u skladu sa svojim ustavom, čak i Vaša. Nama Jugoslovenima nije potreban Vaš savet o tome kako da primenjujemo sopstveni ustav“ ${ }^{\text {“ }}{ }^{\text {‘ }}$ Tako je Jugoslavija i formalno obezglavljena išla u susret svom kraju. Sa Predsedništvom u disfunkciji, vojskom bez vrhovnog komandanta i vladom bez skupštinske podrške, savezni nivo vlasti se sveo na praznu ljušturu. U takvim okolnostima, nije se više postavljalo pitanje da li će izbiti rat, već kada i kako.

\footnotetext{
${ }^{76}$ Politika, 11. 5. 1991, 1.

${ }^{77}$ B. Jović, $n$. $d$., 176.

${ }^{78}$ Stavovi 1 i 2 člana 328 Ustava SFRJ.

79 Voren Zimerman, Poreklo jedne katastrofe. Jugoslavija i njeni rušitelji (Beograd: Dan Graf 2002), 82.
} 
Analizirajući tok jugoslovenskih ustavnih rasprava u periodu poznog socijalizma, Dejan Jović je zaključio da je ta država već tokom osamdesetih godina postepeno odumirala. ${ }^{80}$ Kao ni bilo koji drugi istorijski događaj, tako ni raspad njenog saveznog nivoa vlasti nije bio neumitan, ali jeste predstavljao kulminaciju dužeg i dubljeg procesa tokom kojeg su centrifugalne tendencije definitivno nadvladale integrativni kapacitet Jugoslavije. Dugogodišnja ekonomska i socijalna kriza se dramatično ubrzala nakon raspada SKJ u januaru 1990. Kriza je prerasla u političku paralizu saveznog nivoa vlasti upravo u periodu koji je zahtevao brze transformacije i prilagođavanje promenama u Evropi i svetu, koje je najavio pad Berlinskog zida. Jugoslovenska vlada predvođena Antom Markovićem doduše jeste delovala u tom pravcu, ali se njen reformski program suočavao sa otporom konzervativnih elemenata, čak i u samoj vladi. Vođstvo oružanih snaga SFRJ, koje je personifikovao savezni sekretar za narodnu odbranu Veljko Kadijević, imalo je sopstveni koncept očuvanja Jugoslavije kroz učvršćenje poljuljanog socijalističkog sistema. U ovom raskoraku propadali su pokušaji da se nagomilani ekonomski, društveni, politički i ustavni problemi rešavaju na saveznom nivou, dok su potpuno oprečne političke vizije ključnih jugoslovenskih republika učvršćene nakon izbora održanih tokom 1990: Kučanova Slovenija je radila na promeni spoljnih granice Jugoslavije, Miloševićeva Srbija se bavila prekrajanjem unutrašnjih, a Tuđmanova Hrvatska se pripremala da pokuša i jedno i drugo. Ostvarenje ovih, inače duboko suprotstavljenih ciljeva, zahtevalo je instrumentalizaciju federalnog nivoa vlasti ili njegovu marginalizaciju, kojoj je svako republičko rukovodstvo na svoj način doprinosilo.

Predsedništvo SFRJ je postalo talac suprotstavljenih republičkih interesa, pred kojima je kolektivni šef države potpuno kapitulirao, rastrzan između Borisava Jovića i Stjepana Mesića. Jugoslovenska vlada je nastojala da prevlada takvu fragmentaciju i doprinese očuvanju zemlje, ali joj je nedostajala kontrola nad oružanim snagama, čije je rukovodstvo pak lutalo tražeći uporišnu tačku za očuvanja poretka. Vojska je u tom cilju zveckala oružjem i nastojala da iznudi svoja rešenja planirajući državni udar, ali joj je za takvu opciju nedostajalo kako odlučnosti, tako i podrške u zemlji i van nje. Taj pritisak je, međutim, umrtvio jugoslovensko Predsedništvo i doprineo prenošenju pregovora o političkoj budućnosti Jugoslavije sa saveznog na međurepublički nivo. Republički lideri su simulirali pregovore koji su se svodili na kupovinu vremena. Tako su i vojni i civilni akteri zapravo izbegavali odgovornost za raspad zemlje, koji je postajao ne samo sve neumitniji, već je poprimao nekontrolisane razmere i prerastao u oružani sukob. Sa svakim novim incidentom povećavale su se žrtve, a smanjivale se šanse za miran rasplet jugoslovenske krize. Iz faze odumiranja, Jugoslavija je prešla u fazu u kojoj je aktivno ubijana.

${ }^{80}$ Dejan Jović, Jugoslavija - država koja je odumrla. Uspon, kriza i pad Kardeljeve Jugoslavije 1974-1990 (Zagreb: Prometej, 2003). 


\section{REFERENCE}

- Bilandžić, Dušan. Povijest izbliza. Memoarski zapisi 1945-2005. Zagreb: Prometej, 2006.

- Biserko, Sonja, prir. Vukovarska tragedija 1991. Beograd: Helsinški odbor za ljudska prava u Srbiji, 2007.

- Boljkovac, Josip. Istina mora izaći van. Sjećanja i zapisi prvog ministra unutarnjih poslova neovisne Hrvatske. Zagreb: Golden marketing, 2009.

- Costamagna, Cristian. "Yugoslavia and the Special War in Late Socialism: New Research Perspectives“. Serbian Studies Research, VIII, no. 1, (2017), 121-152.

- Dimitrijević, Bojan. „Na nevidljivoj prekretnici: JNA u 1987. godini“. U: Slobodan Milošević - put ka vlasti. Osma sednica CK SKS. Urednici Momčilo Pavlović, Dejan Jović i Vladimir Petrović, 161-170. Beograd: Institut za savremenu istoriju, 2008.

- Dizdarević, Raif. Od smrti Tita do smrti Jugoslavije. Svjedočenja. Sarajevo: Svjetlost, 2000.

- Dogovoreni rat. Slađana Zarić, Filip Čolović. Informativni program RTS, 2011, Youtube https://www.youtube.com/watch? v=K38-YhyopCU.

- Drašković, Vuk. „Šta hoće generali?“. Srpska reč, 18. 2. 1991, 9-11.

- Drašković, Vuk. Meta. Beograd: Novosti, 2007.

- Goati, Vladimir. Izbori u SRJ od 1990. do 1998. Beograd: CESID, 2001.

- Gow, James. Legitimacy and the Military: The Yugoslav Crisis. New York: St. Martin's Press, 1992.

- Hadžić, Miroslav. Jugoslovenska narodna agonija. Beograd: Dangraf, 2004.

- Hedl, Drago. „Budimir Lončar: Kadijević je za četvrtu generalsku zvijezdicu Miloševiću poklonio JNA“. Jutarnji, 6. 5. 2015, https://www.jutarnji. $\mathrm{hr} / \mathrm{vijesti/hrvatska/budimir-loncar-kadijevic-je-za-4.-generalsku-zvjezdicu-}$ milosevicu-poklonio-jna/383053/.

- JNA 1989-1992: Srpska verzija sloma, Produkcijske kuće Mreža, http://www. youtube.com/watch? $\mathrm{v}=\mathrm{dn} \_$wShzIhN4.

- Jović, Borisav. Poslednji dani SFRJ. Beograd: Politika, 1995.

- Jović, Dejan. Jugoslavija - država koja je odumrla. Uspon, kriza i pad Kardeljeve Jugoslavije (1974-1990. Zagreb: Prometej, 2003.

- Jović, Dejan. Rat i mit. Politika identiteta u suvremenoj Hrvatskoj. Zagreb: Fraktura, 2017.

- Kadijević, Veljko, Intervju RTS, Moskva, 2007. Youtube https://www. youtube.com/watch? v=EQnI63bhAq4.

- Kadijević, Veljko. Protivudar. Moje viđenje raspada Jugoslavije. Beograd: Filip Višnjić, 2010.

- Kamera pamti, Svetolik Milić. Beograd: RTS-Viktorija film, 1995. Youtube https://www.youtube.com/watch? v=9EebziKCLUs.

- Ko izdaje zemlju. Beograd: Informativna služba SSNO, 1991. https://www. youtube.com/watch? v=TxZjGazwZPs. 
- Lučić, Ivo. „Karađorđevo: politički mit ili dogovor?“. Časopis za suvremenu povijest. XXXV, br. 1, (2003), 7-36.

- Mamula, Branko. Slučaj Jugoslavija. Beograd: Dangraf, 2014.

- Marjan, Davor. „'Jedinstvo' - poslednji preustroj JNA“. Polemos. VI, br. 1-2, (2003), 1-47.

- Marijan, Davor. Slom Titove Armije. JNA i raspad Jugoslavije 1987-1992. Zagreb: Golden Marketing, 2008.

- Marković, Ante. „Moja istina o smrti Jugoslavije, razgovori s Gordanom Malićem“, Danas, Beograd, 13-28. 11. 2003. http://www.titomanija.com.ba/eknjige/Moja\%20istina\%20o\%20smrti\%20Jugoslavije.pdf

- Mesić, Stjepan. Kako smo rušili Jugoslaviju. Politički memoari posljednjeg predsjednika Predsjedništva SFRJ. Zagreb: Globus. 1992.

- Nikolić Kosta, i Vladimir Petrović, prir. Od mira do rata. Dokumenta Predsedništva SFRJ. Beograd: Institut za savremenu istoriju-Fond za humanitarno pravo, 2011.

- Petrović, Vladimir. „Raspad SFRJ: kriza, erozija, pat“. Istorija 20. veka. XXXIII, br. 1, (2015), 117-132. https://doi.org/10.29362/ist20veka.2015.1.pet.111-132

- Radan, Peter. „Republika Srpska Krajina and the Right of people to SelfDetermination“. Istorija 20. veka. XXXVI, br. 1, (2018), 9-34. https://doi.org/ 10.29362/ist20veka.2018.1.rad.9-34

- Smrt Jugoslavije: Put u rat. London: BBC, 1995, DVD.

- Svjedoci raspada: Stjepan Mesić, Omer Karabeg. Prag: Radio Slobodna Evropa. 2008. Youtube https://www.slobodnaevropa.org/a/1045335.html.

- Tašić, Predrag. Kako sam branio Antu Markovića. Skopje: Mugri 21, 1993.

- Tatalović, Siniša. „Civilno-vojni odnosi“. Politička misao. XXXIV, br. 2. (1997), 61-82.

- Vukšić, Dragan. JNA i raspad SFR Jugoslavije. Od čuvara do grobara svoje države. Stara Pazova: Tekomgraf, 2006.

VLADIMIR PETROVIĆ, PhD, Senior Research Associate Institute of Contemporary History

Belgrade, Republic of Serbia

vladimir.lj.petrovic@gmail.com

\section{DISINTEGRATION OF THE SOCIALIST FEDERAL REPUBLIC OF YUGOSLAVIA: FROM PARALYSIS TO WAR}

\section{Summary}

This article scrutinizes the disintegration of the federal level of government of the SFRY and its role in transforming the Yugoslav crisis into an armed conflict. This was a culmination of a long process in which centrifugal tendencies overcame the integrative capacity of Yugoslavia. A deep economic and social crisis surged dramatically in the wake of the collapse of the League of Communists of Yugoslavia in January 1990. This crisis led to a paralysis of the federal level of government exactly at the time which called for radical trans- 
formation and adjustment to the global changes signaled by the fall of the Berlin Wall. The Yugoslav government (Federal Executive Council), led by Ante Marković, was spearheading such a reformist program, but it faced ever stronger opposition from the conservative leadership of the armed forces. The agenda of the military, meanwhile, prioritized the preservation of the system, even at the expense of the country's modernization. The space for addressing the mounting problems on the federal level was thus narrowing, enabling constitutive republics to act out their conflicting political projects. Empowered additionally by elections, which were never held on the federal level, leaders of the most influential republics fostered irreconcilable visions: Slovenia under Milan Kučan was planning its independence, hence changing Yugoslav external borders. Serbia under Slobodan Milošević was plotting to redraw internal borders between the republics, and Croatia under Franjo Tuđman was aiming to do both. The realization of such disparate plans called for the instrumentalization or marginalization of the federal government.

In early 1991, this process was set in motion. The growing autonomy of republican leadership resulted in divisions within the SFRY Presidency and its inability to act decisively during the period in which Serbia undermined the federal monetary system, Croatia imported arms from abroad, and Slovenia held an independence referendum. Unchecked by civilian authorities, armed forces were pushing the Presidency into action through systemic pressures, peaking with an aborted coup in mid-March. The Yugoslav Presidency was hence effectively sidetracked, whereas the political dialogue about the Yugoslav future was relegated to summits of republican leaderships. These summits, held in late March and throughout April, did not produce any tangible results, as their actors attempted to legitimize their own positions by avoiding responsibility for the impending collapse and angled to maximize their gains in its course. The remaining federal authorities, Yugoslav government, and the military did attempt to stall this process. However, they failed to coordinate, maneuvering instead to oust each other. These attempts were abandoned in early May, amidst a number of armed incidents. With an increasing number of fatalities, the chances for peaceful resolution of the Yugoslav crisis were dwindling. Yugoslav federal authorities were increasingly unable to influence the course of events. Paralysis of the federal institutions blocked any institutional path toward resolving political problems. As the country moved from collapse into war, the divided representatives of the federal government either abdicated in front of their republican leaderships, or acted in cross-purposes, opening the path to the last stage of the Yugoslav agony.

KEYWORDS: SFRY Presidency, Federal Executive Council, Yugoslav People's Army, disintegration of Yugoslavia, coup, Pakrac, Plitvice, Borovo Selo, Split 